\title{
"Translated" or "Transformed": The Use of Western Hymns in the Evangelization of the Lisu of Southwest China
}

\author{
Aminta Arrington
}

check for updates

Citation: Arrington, Aminta. 2021.

"Translated" or "Transformed": The

Use of Western Hymns in the Evangelization of the Lisu of Southwest China. Religions 12: 772. https://doi.org/10.3390/rel12090772

Academic Editors: John MacInnis and Jeremy Perigo

Received: 31 August 2021

Accepted: 13 September 2021

Published: 15 September 2021

Publisher's Note: MDPI stays neutra with regard to jurisdictional claims in published maps and institutional affiliations.

Copyright: (C) 2021 by the author Licensee MDPI, Basel, Switzerland. This article is an open access article distributed under the terms and conditions of the Creative Commons Attribution (CC BY) license (https:// creativecommons.org/licenses/by/ $4.0 /)$.
Department of Bible and Ministry, John Brown University, Siloam Springs, AR 72761, USA; AArrington@jbu.edu
Abstract: Translated western hymns have a bad reputation in missiology. The term "translated" seems to convey a less than authentic expression of Christian faith. However, that was not how it happened when the Lisu of southwest China were evangelized by missionaries from the China Inland Mission in the 1920s and 1930s. The Lisu people exerted much more agency over their translated western hymns than the term "translated" implies. While the kernel of melody and message remained intact, four-part harmonies replaced unison singing. A cappella replaced piano or organ accompaniment. Phrases meaningful in a Victorian context were transformed into phrases meaningful in a Lisu mountain context. Abstract theological terms were replaced by concrete phrases. Western rhyming schemes were laid aside and Lisu poetic couplets were used instead. The end result is that in the everyday arena, in the practical living out of what it means to be a Christian for a communal and still largely oral-preference people such as the Lisu, the Lisu Christian hymns are the centerpiece of worship and devotion, of prayer and penitence. In other words, in the process of cross-cultural transmission, the Lisu hymns were not so much translated, as they were transformed.

Keywords: Lisu people (southwest China); hymns; worship (Christianity); church music; China; missions; minorities; orality

\section{Introduction}

The Lisu Easter Festival was approaching.

"Can you teach me an Easter hymn?" I asked Pastor Timothy.

I had been living high above a small village in the Nujiang Valley of China's Yunnan Province with Pastor Timothy, his wife, his parents, and his two daughters as part of my fieldwork studying the Christian faith and practice of the Lisu, one of China's 55 minority groups. In the mornings, he taught me the Lisu language for two hours. In the afternoons and evenings, we took part in the daily chores of farming: gathering tall grasses for the pig slop, planting corn, frying bread or eggs over the open fire in the kitchen, and washing dishes. On Wednesday and Saturday evenings, and three times on Sunday, we all followed the path down the mountain, hymnbooks and Bibles carried in our embroidered Bible bags, to the village for church services, where Pastor Timothy usually preached.

Pastor Timothy chose to teach me hymn number 33 in the Lisu hymnbook, "When I Survey the Wondrous Cross," written by Isaac Watts and first published in Hymns and Spiritual Songs in 1707. We started learning the first verse:

\section{JO CE; SU AW W TI. D: M-. $\quad$ Creator of man, my great sovereign king; \\ W: C; SU $\wedge$ W SI.. d D: M-. $\quad$ Creator of all, my Lord and master.}

Lisu poetry, like much oral poetry, unfolds according to synonymous parallelism, in which meanings flow out in two lines, the second line restating or amplifying the first one. In translating this hymn, the missionaries along with their Lisu translator-helper chose to translate according to the parameters and principles of Lisu oral poetry (Arrington 2015b).
Il: HO: NU TV NI, ZO SI NYI-
One group hated you;
II B $\mathrm{NU}$ T $\forall \mathrm{NI}, \mathrm{V}$ ᄀ., SI NYI-
The other half was angry with you. 
The poetic parallelism meant that the Lisu version of "When I Survey" extends to six verses, unlike the English original, which usually has just four.

NU T $\forall>1$., NYI VI C $\dashv \mathrm{O}$, SI-. $\quad$ They slandered you and tied you with a rope;

NU T $\forall$ Jח.. NYI SI, D., D7 SI-. $\quad$ They prosecuted you and hit you with a rod.

In fact, the word "cross", appearing in the title and first line of the English version, does not appear until the last line of the third verse in the Lisu version.

$\mathrm{NU} \perp \forall ;$ SE; DU KW NI, X._LO=

LA; BO T7. DU KW NY X._ LO=

When they killed you, you were distressed;

When you were on the cross, you were worried.

In addition to the use of synonymous parallelism, the abstract phrasing common to English hymns is replaced by concrete phrasing in the Lisu version. In verse three of the English version, this line is found:

See from his head, his hands, his feet,

Sorrow and love flow mingled down.

Such a line is beautiful and appropriate for the context in which it was originally written; it allows hymn singers in highly literate cultures in North America and England to reflect within their own psyche on how the physical and emotional pain of Christ intertwined in the moment of his passion. Oral thought patterns in such cultures as the Lisu, however, do not tend toward such quiet, individual reflection. Rather, important thoughts are expressed and shared, for if not they are lost. They exhibit what Walter Ong called a closeness to the human lifeworld (Ong [1982] 2002, pp. 42, 49). It is not surprising, then, that the Lisu translation of these lines is quite different:

HO., JU: $\perp \forall ;$ NYI Xก: DO L SI-. $\quad$ They hammered you with nails, you bled;
A. L: K. NYI Xก: YI L SI.
They pierced your side, blood and water flowed.

Love and sorrow have been replaced by hammers and nails, by blood and water. Rather than allude to the pain, cruelty, and violence associated with the death of Christ, as the English version does in its literary baroque style, the Lisu version lands squarely, shockingly, in the middle of it. Pastor Timothy told me that when he sings this hymn, he truly feels the pain and anguish that Christ went through to save his soul. In the Lisu translation, the cadence and rhyming, the balance and counterbalance, all combine to produce a hymn that appeals to the poetic sensibilities of the Lisu mind (Arrington 2015a).

The Lisu of southwest China were evangelized in the 1920s by missionaries from the China Inland Mission, led by pioneering missionary J.O. Fraser. The Lisu were a musical people, and key to their initial evangelization was the use of translated western hymns. Over the course of two years, from 2012 to 2014, I conducted five months of fieldwork among the Lisu Christians living in the Nujiang Valley of China's Yunnan province. One of my most salient findings was that translated western hymns remain central to Lisu Christian worship.

This is striking, for translated western hymns have long had a bad reputation in missiology. In fact, there are several assumptions about the use of translated hymns in mission contexts. There is the assumption that translated hymns are not meaningful to local Christians (Chenoweth and Bee 1968). It is also assumed that translated hymns represent western missiological hegemony (King 2008). Some have called translated hymns "short cuts" (Nketia 1958). Finally, there is the assumption that translated hymns prevent local people from understanding the gospel (King 2008, p. 5). In fact, the renowned missionary anthropologist Paul Hiebert stated that "Many missions continued to exercise authority, to use translated hymns, and to impose Western forms of church polity, but some encouraged the autonomy of young churches, the use of local music, and the adoption of indigenous forms of church organization" (Hiebert 1994, p. 82). Hiebert places the use of "translated hymns" in a list of three regrettable actions relating to the over-exercise of western control, and the use of "local music" in the list of three more enlightened methods which rightly 
give the locals autonomy over their Christian lives. While in general I strongly support Hiebert's assertion that local Christians be given authority over their own churches, I contend in this paper that translated western hymns do not fall easily into categorization as a practice impeding this goal. In fact, the story of Lisu Christianity shows the opposite.

The early missionaries to the Lisu were musicians. J.O. Fraser, an engineer and concert pianist, joined the China Inland Mission (CIM) and sailed for China in 1908. While completing Chinese language studies at the CIM Language School in Anhui province, he met John McCarthy, the CIM superintendent for Yunnan Province, who was visiting the language school to select some missionary recruits for the mountainous province in southwest China. "Send me Fraser, and anyone else you like," McCarthy wired back to headquarters in Shanghai (Fraser 1963).

Upon arrival in Yunnan, Fraser met the Lisu in the local markets and felt immediately drawn to them, although he was scheduled to begin work with the Miao people in the eastern part of the province. Finally, in 1913, the CIM designated Fraser for full-time work with the Lisu. He was a lone western missionary, traveling through the mountains of western Yunnan on the back of a donkey, sitting around fires with his Lisu hosts learning the language and the culture. While he proved an adept linguist and adapted well to Lisu culture, his efforts at evangelization were less successful. By early 1916, he had few converts. At times he would hold Sunday services, and no one would show up (Taylor 1944). Fraser decided that God's time for the Lisu was not yet ripe. He planned to write a letter to the mission requesting a return to his original designation to work with the Miao. "But before I write that letter," Fraser stated, "I will take my final visit round my district. Just one more round" (Conversation with Mr. Fraser 1934, p. 4).

However, in each village he visited on his farewell tour, families upon families approached him ready to turn toward Christ. By the end of 1916, over 120 families had converted, but they had little understanding of their new faith. Fraser took to teaching them hymns as a means of conveying the Christian doctrine. "The hymns are the jam, and the Gospel is the powder to be taken," he said (Taylor 1944).

In 1927, Fraser took on the role of CIM superintendent for Yunnan province. However, though he was no longer itinerating through Lisuland, his presence was still felt. Together with Ba Thaw, a Karen tribesman from Burma, Fraser created a written Lisu script and began work on translating a catechism, hymnbook, and gospel portions. Further, Fraser laid out the three-self principles for the Lisu work based on the writings of Roland Allen, among others (Kuhn n.d., p. 9). ${ }^{1}$

The first principle was self-supporting, meaning that the Lisu church would support itself financially, and no funds, either personal or from missionary organizations, would be given to the church or to Lisu people. As Leila Cooke stated,

Mr. Fraser charged us very carefully not to spoil the Lisu with gifts or money, and that we should not pay even for the services of a language teacher, as the work was to be entirely self-supporting. We got around the difficulty by asking different ones to give a month each to teaching us, and count it as work done for the Lord. We had a few pocket knives worth about ten cents apiece, and gave one of those at the end of each month as a token of appreciation for the voluntary service rendered. When Mr. Fraser heard of this he wrote us saying, "Please do not reward them even ten cents' worth. Let their labor be entirely for the Lord".

$$
\text { (Cooke 1947, pp. 18-19) }
$$

In addition to being self-supporting, the Lisu church was self-governing. As Isobel Kuhn, another second-generation missionary, put it:

The Lisu church, being founded along indigenous lines, was self-governing. The missionary gave advice when asked, and likewise preached only when invited. In each Christian village there was one elected as service leader, and this one wrote down on the blackboard the names of those he wished to preach during 
the coming week. If the missionary's name did not appear, he did not preach but sat in the audience while the selected national Christian officiated.

$$
\text { (Kuhn [1947] 1995, pp. 134-35) }
$$

The third principle was self-evangelizing. Fraser ensured that missionaries remained in the background, usually conducting Bible training for church leaders, and that the Lisu themselves were at the forefront of evangelism. As early as 1919, Fraser wrote about the Nujiang Valley: "That district must be evangelized, but I want to find suitable nationals to go first" (Kuhn [1947] 1995, p. 19). It is within this context that the Lisu hymns were translated, a context that sought to, and largely succeeded at, giving the Lisu church full agency in the development of their faith.

With J.O. Fraser working in other fields in China, or busy with administrative tasks as superintendent, in the late 1920s Allen and Leila Cooke took on frontline roles with the nascent Lisu church. Both Allen and Leila attended the Bible Institute of Los Angeles (now Biola University). They were also both musicians, Allen on the violin and Leila on the piano. Fraser called them, "Our missionary-musicians" (Fraser 1933).

As the Lisu church was now growing and maturing, the Cookes focused on conducting short-term Bible schools as well as working on translation. Translation of the Bible and the hymnbook proceeded together, with the same translator-helper, a Lisu by the name of Fish Four, working on both. The Cookes taught the Lisu to sing in parts, which they took to immediately. After a few years, the Cookes moved to the Nujiang Valley, the site of my fieldwork, so that they could be in a purer Lisu-language environment for the purposes of translation. It was here that Leila Cooke sought out some Lisu oral poets to give her more words to use in translation: "Lisu poetry is very similar in style to that of the precious Psalms of David. Each thought is repeated with the same number of words, and companion phrases to express it" (Cooke 1947, p. 30).

Very quickly, singing hymns became the centerpiece of Lisu Christian practice. Hymns were not just sung in church. Lisu Christians sang hymns when they worked in the fields (Cooke 1932, p. 74). They sang hymns while traveling (Kuhn [1947] 1995, p. 62). They sang hymns when they attended Bible school (ibid., pp. 21-22).

In the course of my own fieldwork, I noticed the same. Lisu Christians sang hymns in times of personal devotion. They referred to hymns when seeking to understand doctrine. They sang hymns to declare their communal identification, by expressing public, poetic truth. ${ }^{2}$ They sang hymns to learn to read the Lisu language, for the hymnbook was one of few public documents containing their own script. Furthermore, just as during the mission period, they sang hymns when they attended Bible school.

Long before Christian communities were internationally networked, the Lisu sang hymns written and composed on continents far from their own, yet sang them because they were grounded in their local Christian practices and meaningful in their own local context. Ingalls et al. (2018) define localization as "the process by which Christian communities take a variety of musical practices-some considered 'indigenous,' some 'foreign,' some shared across spatial and culture divides; some linked to past practice, some innovative-and make them locally meaningful and useful in the construction of Christian beliefs, theology, practice, or identity" (p. 13).

In the Lisu case, such localization occurred because the Lisu hymns were not so much translated-a term that can often imply unidirectional communication of meaning from source to recipient-as they were transformed into a new thing, a work of many hands that found fresh life in a soil far from its origin.

\section{Musically Transformed}

In the beginning of my fieldwork with the Lisu, when so much about all that I felt church should be felt strange and different, hearing a hymn melody was the only thing familiar. Whether it was "What a Friend We Have in Jesus" or "Trust and Obey", the melody signaled to me not just which hymn we were singing, but also the topic we were singing about. 
Yet even in the music, the realm that at first glance seems most similar, transformation leading to localization had still occurred. The first transformation was from unison singing to singing in four-part harmony. From the beginning of their Christian history, the Lisu took to singing in parts. In one church, they even sat according to their part, so that they could all easily sing together. For Lisu Christians, a portion of their identity is in the part that they sing, whether soprano, alto, tenor, or bass.

In addition, the Lisu hymns are sung a cappella. At first glance, singing a cappella, instead of accompanied by a piano or other instrument, might seem like a stylistic choice, as it is in most of the west. While singing hymns a cappella is now certainly a key part of the Lisu musical aesthetic, this initial choice was not made for reasons of style. For the Lisu people in the mission period, even if they could afford a piano, the demanding lifestyle of subsistence farming did not allow for the hours of practice that mastery of such a musical instrument required. Thus, if a piano had been brought into the Nujiang Valley—and the mountainous terrain and lack of roads made such a feat near impossible - the ones to play it would not have been locals, but the missionaries. Singing a cappella, on the other hand, put everyone-missionary and local—on the same level. This meant that very early in the process of their evangelization, local Lisu Christians had autonomy over hymn selection and hymn leading.

Further, a cappella singing had roots in pre-Christian Lisu culture. Though Lisu culture was highly musical before their evangelization, involving both string guitars and choral singing, they did not mix the two genres. Lisu choral singing was unaccompanied, both before the arrival of missionaries and after (Larsen 1984, p. 44).

Singing hymns a cappella in four-part harmony led to a structural change in the Lisu hymnbook: the use of number notation instead of staff notation. While staff notation is useful for piano accompaniment, it can make it difficult to tease out one's choral part. Number notation, on the other hand, lays out all four parts in four distinct lines that can easily be sung. I never met a Lisu who could not sightread number notation.

The move to eschew piano accompaniment might seem like an obvious choice given the Lisu's subsistence lifestyle and mountainous terrain, as well as Fraser's policy that that the Lisu church be self-supporting. However, the effect of this choice was to put the Lisu hymnody firmly in the hands of the Lisu Christians themselves, removing any need for a missionary expert pianist to have a role. Still today, every Lisu Christian is a singer, and every pastor is a worship leader.

\section{Poetically Transformed}

The lines of a hymn are lines of poetry, and here, too, the Lisu hymns have been transformed. In an effort to find more words to use in the translation of the Bible, Leila Cooke used words from Lisu funeral chants and oral poetry, highly poetic language not used in the course of daily life. One of the poetic constructions she found in the highly stylized oral poetry were four-word couplets, an arrangement of three words with one of the words repeated, in either an A-B-C-B or A-B-A-C construction. While the three words were usually concrete forms, their use together in the four-word couplet expressed an abstract idea. An example is:

$$
\begin{aligned}
& \text { NI...X...MY...X } \\
& \text { heart ... worry ... soul ... worry }
\end{aligned}
$$

While distress, worry, and anxiety are words reflecting concern about everyday affairs, their bundling together into a single morpheme conveys a deep grief and sorrow. "NI...X...MY...X" was used to translate the word "griefs" in the line "All our sins and griefs to bear" in hymn number 242 in the Lisu hymnbook, "What a Friend We Have in Jesus". "NI...X...MY...X” was also used in Bible translation to convey the deep suffering Jesus experienced in the Garden of Gethsemane when he asked his disciples to watch and pray with him before his crucifixion (Arrington 2020). 
In choosing to use poetic constructions that were already present within the Lisu language, as opposed to coining a new term when an existing Lisu term was not readily available, the hymn translators were able to appeal to deep places in the Lisu psyche, to feelings usually only expressed in the context of ceremonial grief.

However, while the use of "NI...X...MY...X " allowed the Lisu Bible and Lisu hymns to carry deep cultural meaning, the transformation, in this case, went both ways. The couplet itself now expresses a theological meaning not present in its previous ceremonial usage. It is no longer just sorrow, but sorrow that Jesus himself experienced, and sorrow that he now carries on behalf of those who, in their singing of the hymn, are signifying their trust in him. Thus, not only has the hymn "What a Friend We Have in Jesus" been transformed by its use of this four-word couplet, but the four-word couplet "NI...X...MY...X" has itself been transformed. While it previously meant inconsolable sorrow, its placement within this hymn has given its meaning further nuance: sorrow together with a portion of comfort.

Furthermore, even with the discovery of these abstract words, there were still theological concepts missing entirely from the Lisu language, as is to be expected in an oral culture that did not come from a Christian basis. As such, there were some terms that did have to be coined for Bible and hymn translation. In some cases, the missionaries and their translator-helpers coined terms using Chinese equivalents. However, in other cases they used existing Lisu words and combined them to form a new four-word couplet with new meaning. An example is the word for blessing, a word not previously existing in the Lisu language before their evangelization, but a critical term to use in the translation of the Bible and hymns. This meaning was conveyed by constructing a new four-word couplet: "good luck ... person ... fortune ... person". This couplet is used in the translation of the hymn "Come Thou Fount of Every Blessing", hymn number 75 in the Lisu hymnbook.

These oral poetic forms were containers of deep cultural meaning for the Lisu people, meaning preserved for the people not in dictionaries or history books, but in the spoken words of elderly oral poets. As such, however, these forms and their meanings were inherently vulnerable as older generations began to pass away without passing down this knowledge to the younger generations who attended Chinese-language medium schooling. Because of translation, these cultural forms are preserved in the Lisu Christian hymnody and the Lisu Bible.

\section{Semantically Transformed}

In addition to their musical and poetic transformation, the Lisu Christian hymns have been semantically transformed. This sematic transformation is seen vividly in "When I Survey the Wondrous Cross", described at the beginning of this article. In this hymn, the allusive baroque poetry of the original English version was translated into stark and concrete terms, better reflecting the linguistic patterns of Lisu oral culture.

At other times semantic changes in translation resulted from the requirement to fit Lisu words, thoughts, and phrases to the rhythm and meter of the hymn. For example, hymn number 1 in the Lisu hymnbook is "To God Be the Glory". The chorus of this hymn begins as shown below in English and in Lisu:
Praise the Lord!
SI.. d T $\forall$
Praise the Lord!
$D O, M U, L \forall=$

The English repeats the line "Praise the Lord!", but sentences in the Lisu language are more expansive than their English counterparts. The Lisu version, thus, contains no repetition; it requires the entire six notes of this musical phrase to express the same thought.

However, lack of repetition does not fully explain what has occurred. A retroversion of the Lisu version back into English is helpful here:
SI.. d TV
To the Lord
$D O, M U, L V=$
Let us praise 
The end of each line in the Lisu version contains a particle, $T \forall$ in the first and $L \forall$ in the second. The first particle, which might be translated as "to", signifies exactly who is being praised, in this case, "the Lord". While meeting the requirements of Lisu syntax, this translation remains fairly close to the English original.

The use of the second particle, $L \forall$, however, introduces new meaning into this hymn. This particle is commonly affixed to verb phrases with the idea of "let us", as in "let's go", "let's run", or in this case, "let us praise". In other words, there is a communal element brought into the hymn. While the English version feels like a summons to an individual to give praise to the Lord, in the Lisu version the community is summoning itself, as a group, to praise the Lord together. In other words, the hymn has been socially transformed.

\section{Socially Transformed}

It is here, in the social transformation, that perhaps the greatest localization has occurred. The semantic change described above both reflects and encourages the social role that hymns play in the communal Christian life of the Lisu people. The "Let us" wording of the hymn corresponds with the shared experience of singing together, acting out their embodiment as a church community that needs one another. As J.R. Watson stated, "The singer becomes part of a group process, engaged, committed, the vocalized ' $\mathrm{I}$ ' or ' $w \mathrm{we}^{\prime}$ ' of the hymn becoming part of the involvement with public worship" (Watson 1999, p. 22).

Singing in four-part harmony also reinforces communal feeling. When entering a Lisu church sanctuary, even the tiny rooms built of stone with one lone lightbulb hanging from its own cord that served as sanctuaries during my fieldwork, the reverberation of soprano and alto, of tenor and bass across the room let each embodied singer present know that their voice was at its most beautiful and meaningful when it was joined together with others. Singing in four-part harmony further encouraged a mindfulness of those with whom one is singing, as one sought to blend their voice together with that of the others. Singing in four-part harmony created an awareness of the unison agreement around creed, doctrine, and belief, a togetherness which the singers took with them out of the sanctuary and into their homes and fields (Arrington 2020).

\section{Conclusions}

While the English versions of many hymns that have been translated into Lisu now find themselves on the periphery of Christian life in their original contexts, quite the opposite has happened with these same hymns in Lisuland. ${ }^{3}$ Translated Victorian-era hymns remain at the center of Lisu Christian belief and practice. In fact, it is hard to overestimate the role that the hymnbook has in Lisu Christian life today. Part of the reason is that these hymns were not just translated: they were transformed. Translation in mission contexts can imply that while the literary idiom has changed, the ideas and meaning have remained unchanged, flowing from source to recipient in one direction. In the case of the self-supporting, self-governing, self-evangelizing Lisu church, however, the dialogue between missionary and local, between literate and oral, between western culture and Lisu culture, ultimately allowed the Lisu church to localize these transformed hymns and claim them as something wholly their own.

Localization, for the Lisu, did not begin when they received the translated hymns. Localization began before hymn translation even occurred, in the building of a three-self mission structure that ensured the local church had autonomy over their own worship. It lasted throughout the translation process when their own rituals and ceremonies were intentionally mined, allowing new theological ideas to be explained using traditional poetic phrases. Localization continued upon receipt of the translated hymns, when these hymns were sung a cappella in four-part harmony, reinforcing aspirations for a Christian life focused on togetherness. Furthermore, localization has continued in the following decades, as the Lisu church sings these hymns that no longer simply carry the Christian doctrines as J.O. Fraser intended, but now also carry their own story. 
Funding: A portion of this research was funded by a John Brown University Summer Scholars Fellowship.

Institutional Review Board Statement: The study was conducted according to guidelines of Biola University, and approved by the Protection of Human Rights in Research Committee (PHRRC) of Biola University in August of 2013.

Informed Consent Statement: Informed consent was waived due to the political situation within the country at the time of my research. At all times, my research was conducted under the auspices and protection of the local Lisu churches.

Data Availability Statement: Not applicable.

Conflicts of Interest: The author declares no conflict of interest.

\section{Notes}

1 Such as Missionary Methods: St. Paul's or Ours (1912) and The Spontaneous Expansion of the Church and the Causes Which Hinder It (1927).

2 In using the term "poetic truth", I am taking a cue from Walter Fisher (1989) narrative paradigm.

3 Some of the oratorios in the back of the Lisu hymnbook, such as number 289, "The Heavens Are Telling", were translated into Lisu during the mission period, and then their originals were lost to the western canon.

\section{References}

Arrington, Aminta. 2015a. Christian Hymns as Theological Mediator: The Lisu of South-west China and Their Music. Studies in World Christianity 21: 140-60. [CrossRef]

Arrington, Aminta. 2015b. Orality, Literacy, and the Lisu Linguistic Borderlands. Missiology 43: 398-412. [CrossRef]

Arrington, Aminta. 2020. Songs of the Lisu Hills: Practicing Christianity in Southwest China. University Park: Penn State Press.

Chenoweth, Vida, and Darlene Bee. 1968. On Ethnic Music. Practical Anthropology 15: 205-12.

Conversation with Mr. Fraser. 1934. December 21. Box 11, Papers of Frederick Howard Taylor, China Inland Mission Archive, SOAS Archives, University of London.

Cooke, Leila R. 1932. Honey Two of Lisu-land. London: China Inland Mission.

Cooke, Leila R. 1947. Fish Four and the Lisu New Testament. Shanghai: China Inland Mission.

Fisher, Walter R. 1989. Human Communication as Narration: Toward a Philosophy of Reason, Value, and Action. Columbia: University of South Carolina Press.

Fraser, J. O. 1933. Letter to Mrs. Howard Taylor, October 31, 1-2. Box 11, Papers of Frederick Howard Taylor, China Inland Mission Archive, SOAS Archives, University of London.

Fraser, J. O. 1963. Fraser and Prayer. London: Overseas Missionary Fellowship.

Hiebert, Paul G. 1994. Anthropological Reflections on Missiological Issues. Grand Rapids: Baker.

Ingalls, Monique M., Muriel Swijghuisen Reigersberg, and Zoe C. Sherinian. 2018. Introduction: Music as Local and Global Position. In Making Congregational Music Local in Christian Communities Worldwide. Edited by Monique M. Ingalls, Muriel Swijghuisen Reigersberg and Zoe C. Sherinian. New York: Routledge.

King, Roberta. 2008. Music in the Life of the African Church. Waco: Baylor University Press.

Kuhn, Isobel. 1995. Nests Above the Abyss. Singapore: Overseas Missionary Fellowship. First published 1947.

Kuhn, John B. n.d. Memoirs of J. O. Fraser. Collection 215, Records of Overseas Missionary Fellowship, Box 4, Folder 55, Billy Graham Center Archives, Wheaton, IL.

Larsen, Hans P. 1984. The Music of the Lisu of Northern Thailand. Asian Folklore Studies 43: 41-62. [CrossRef]

Nketia, Joseph H. 1958. The Contribution of African Culture to Christian Worship. International Review of Mission 47: 265-78. [CrossRef]

Ong, Walter J. 2002. Orality and Literacy: The Technologizing of the Word. New York: Routledge. First published 1982.

Taylor, Howard. 1944. Behind the Ranges: Fraser of Lisuland Southwest China. London: China Inland Mission.

Watson, J. R. 1999. The English Hymn: A Critical and Historical Study. New York: Oxford University Press. 